G. et al. (2017), BSACI guideline for the diagnosis and management of allergic and nonallergic rhinitis (Revised Edition 2017; First edition 2007), Clin Exp Allergy. 47(7), 856-889.

5. Bộ Y' Tế (2016), Hướng dẫn quy trình kỹ thuât chuyên ngành Giải phâuu bệnh, Tễ bào học, Nhà xuất bản Y học, Hà Nội.

6. Kaya D., Demirezen S. ,Beksaç M. S. (2012), The presence of eosinophil leucocytes in cervicovaginal smears with Actinomyces-like organisms: Light microscopic examination, J Cytol. 29(4), 226-9.
7. Berkiten G., Aydoğdu I., Kumral T. L. et al. (2018), Nasal eosinophilia in nasal smears of patients with persistent and intermittent allergic rhinitis, J Laryngol Otol. 132(11), 1018-1021.

8. Ciprandi G., Buscaglia S., Pesce G. et al. (1995), Minimal persistent inflammation is present at mucosal level in patients with asymptomatic rhinitis and mite allergy, J Allergy Clin Immunol. 96(6 Pt 1), 971-9.

9. Wang D. Y. (2005), Risk factors of allergic rhinitis: genetic or environmental?, Ther Clin Risk Manag. 1(2), 115-23.

\title{
ĐÁNH GIÁ TÁC DỤNG CỦA LUMBROKINASE TÁI TỔ HỢP TRÊN CHUQ̣̂T NHẤT GÂY NHỒI MÁU NÃO TRONG GIAI ĐOẬN CẤP
}

\author{
Trương Ngọc Hiển*, Ngô Hồng Huế*, Nguyễn Thái Biềng*, \\ Chu Thị Thanh Hằng*, Chử Văn Mến*
}

\section{TÓM TẮT}

Mục tiêu: Triển khai mô hình nhồi máu não trên chuột nhắt trắng, đánh giá tác dụng của lumbrokinase tái tổ hợp trong việc hồi phục chức năng vận động của chuôt nhắt trắng trong giai đoan cấp. Phương pháp: Mô hình gây nhồi máu não tại động mạch não giữa của chuột nhắt trắng theo phương pháp của Cyrille Orset và cộng sự (2007), các phương pháp đánh giá tác dụng của thuốc trên mức độ tổn thương chức năng vận động của chuột trong giai đoạn cấp. Kết quả và kết luận: Mô hình gây nhồi máu não trên chuột nhắt trắng được sử dụng trong nghiên cứu này cho phép tao ra một cuc máu đông có bản chất sát với thực tế lâm sàng; chể phẩm lumbrokinase tái tổ hợp mức liều $200 \mathrm{mg} / \mathrm{kg}$ có tác dụng hồi phục chức năng vận động của chuột trong điểu trị nhồi máu não trên mô hình thực nghiệm trong giai đoạn cấp.

Tư khóa: lumbrokinase, mô hình gây nhôi máu não, chuột nhắt.

\section{SUMMARY \\ EFFECT EVALUATION OF RECOMBINANT LUMBROKINASE ON ACUTE BRAIN INFARCTION MICE MODEL}

Objectives: Acute brain infarction was induced to evaluate the effect of recombinant lumbrokinase on mice's motor function. Methods: Model of acute cerebral infarction in the middle cerebral artery of mice according to the method of Cyrille Orset et al, methods to evaluate the effect of drugs on the degree of motor function damage in mice during the acute phase. Results and conclusion: The cerebral infarction mice model used in this study allowed the creation of a blood clot that are similar to clinical

*Hoc viên Quân y

Chịu trách nhiệm chính: Chử Văn Mến

Email: chuvanmen@vmmu.edu.vn

Ngày nhận bài: 10.9.2021

Ngày phản biên khoa học: 2.11 .2021

Ngày duyệt bài: 12.11.2021 reality; the recombinant lumbrokinase $200 \mathrm{mg} / \mathrm{kg}$ recover motor function of cerebral infarction mice on an experimental model during the acute phase.

Keyword: lumbrokinase, model of cerebral infarction, mice

\section{I. ĐĂT VẤN ĐỀ}

Đột quy não luôn là vấn đề thời sự của ngành y tế ở tất cả các quốc gia trên thế giới. Ở Mỹ, đột quy. não là nguyên nhân tử vong đứng hang thử bas au bệnh tim mạch và ung thư. Theo hội tim mạch Mỹ (AHA), ước tính Mỹ có khoảng 4,7 triệu bệnh nhân đột quy còn sông và 780 nghìn bệnh nhân mới mắc hoặc tái phát đột quy trong một năm.[1]

Bệnh tai biến mạch máu não gồm 2 loại chính là nhồi máu não và xuất huyết não, 80\% đột quy là do nhôi máu não.[2] Nguyên nhân chủ yếu là do xuất hiện cục máu đông gây tắc mạch và cản trở lưu thông máu. Do đó, việc làm tan cục máu đông đóng vai trò quan trọng trong việc điều trị bệnh này.

Về phương diện lâm sàng, Lumbrokinase là một peptid tổng hợp từ giun đất được xem là thuốc tan huyết khối đặc hiệu, sử dụng làm thuốc uống vì có thể được hấp thu từ ruột vào máu và hoạt hóa hệ thống fibrin nội sinh. Một ưu điểm lớn của lumbrokinase so với các thuốc điêu trị bệnh tắc nghẽn mạch thông dụng khác thường được sử dụng làm thuốc tiêm (như tPA (tissue type plasminogen activator), urokinase và streptokinase) là không có tác dụng phụ, không gây chảy máu hệ thống, giá thành rẻ.[3] Lumbrokinase được cho là thuốc tiêu sợi huyết có hiệu quả cao, đã được sử dụng dự phòng và hỗ trợ điêu trị nhồi máu não tại nhiêu nước như Nhật Bản, Hàn Quốc, Trung Quốc và Canada... 
Với đề tài trên, chúng tôi tiến hành giải quyết các mục tiêu sau: Triển khai được mô hình nhồi máu não trên chuột nhắt trắng, đánh giá được tác dụng của lumbrokinase tái tổ hợp trong việc hồi phục chức năng vận động của chuột trong giai đoạn cấp.

\section{VẬT LIỆU VÀ PHƯƠNG PHÁP NGHIÊN CỨU: \\ 1. Chế phẩm nghiên cứu:}

- Lumbrokinase (LK) tái tổ hợp, do viên Công nghệ sinh học thuộc viện Hàn lâm khoa học Việt Nam bào chế, đat tiêu chuẩn cơ sở.

- Boluoke (lumbrokinase) của Canada RNA Biochemical Inc được dùng làm thuốc tham chiếu.

\section{2. Động vật nghiên cứu:}

Chuột nhắt trắng trưởng thành, chủng Swiss, giống đực, chuột khỏe mạnh không bị bệnh, được nuôi trong phòng thí nghiệm kiểm soát nhiệt đô theo chu kỳ $12 \mathrm{~h}$ sáng/ $12 \mathrm{~h}$ tối, cân nặng mỗi con tại thời điểm bắt đâu thí nghiệm là 18 - 22g.

Đông vật thí nghiệm do Ban Cung cấp Động vật thí nghiệm - Học viện Quân y cung cấp, nuôi dưỡng trong phòng nuồi động vật thí nghiệm ít nhất một tuần trước khi tiến hành thí nghiệm.

Đông vật ăn thức ăn theo tiêu chuẩn thức ăn cho động vật nghiên cứu, nước sạch đun sôi để nguội uống tự do.

\section{Phương pháp nghiên cứu:}

Để đánh giá tác dụng hồi phục tổn thương não do đột quỵ. nhồi máu não, chúng tôi tiến hành nghiển cứu trên mô hình gây nhồi máu não tại động mạch não giữa của chuột nhắt trắng theo phương pháp của Cyrille Orset và cộng sự (2007) [4].

*Mô hinh gây nhồi máu não. Dựa trên việc thrombin là chất khởi đâu và trung gian chính của sự hình thành cục máu đông tại chỗ. Yếu tố gây đông máu Thrombin được tiểm vào động mạch não giữa để kích thích quá trình tự đông máu của chuột qua đó hình thành nên cục máu đông có bản chất sát với thực tế lâm sàng.

Tiến hành: Trước khi tiến hành phẫu thuật, chuẩn bị pipette bằng cách dùng thiết bị kéo điện cực (electrophysiology puller, PC-10, Narishige) để kéo ống thủy tinh cõ nhỏ làm thành pipette. Thrombin tinh khiết được hút vào pipette. Chuột được gây mê bằng Nembutal đường phúc mạc với liều $40 \mathrm{mg} / \mathrm{kg}$ thể trọng, sau đó được cố định trên hệ thống định vị (stereotaxic device, M2009S). Đường rạch được thực hiện tại vị trí giữa tai phải và mắt phải; cơ thái dương được tách ra khỏi xương thái dương bằng tăm bông. Một lỗ nhỏ đường kính khoảng
$1 \mathrm{~mm}$ trên xương sọ được khoan bởi máy Proxxon (Nhật Bản) với mũi khoan đường kính $0,5 \mathrm{~mm}$. Màng cứng được rạch và động mạch não giữa (MCA) được bộc lộ. Sau khi pipette được đưa vào $M C A, 1 \mu l a$ - thrombin được đẩy và̀o lòng mạch nhằm tạo cục huyết khối. Pipette được rút bỏ sau 10 phút kể từ khi tiêm thrombin để bảo đảm cục huyết khối đã ổn định. Kháng sinh Gentamicine $80 \mathrm{mg} / \mathrm{ml}$ (Việt Nam) được nhỏ 3 giọt tại bề mặt xương sọ bộc lộ trong quá trình phầu thuật. Sau đó, vết mổ được đóng lại.

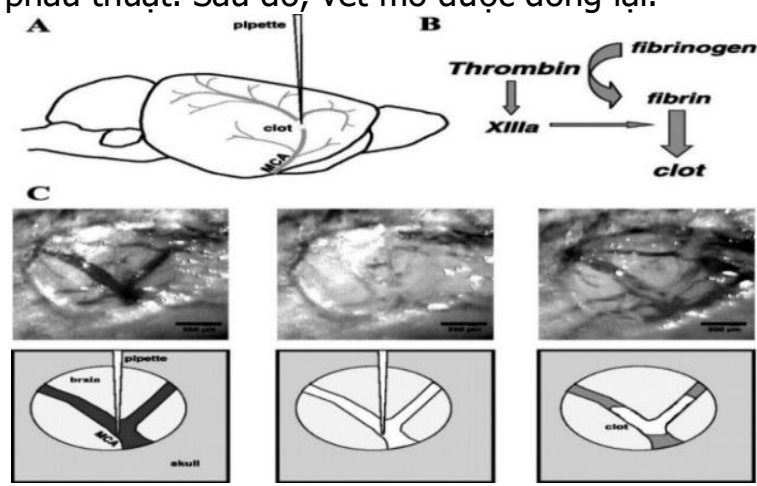

Hình 1. Qui trình gây nhồi máu tại động mạch não giữa của chuột nhắt theo Cyrille Orset và $C S, 2007$ ( A. Vị trí tiêm thrombin gây nhồi máu. B. Minh họa quá trình hình thành cục máu đông. $C$. Hình ảnh chụp trên kính hiển vi và sơ đồ mô tả các bước khác nhau trong quá trình gây cục máu đông).

*Phân lô chuột nghiên cứu và cho uống thuốc Chuột nhắt trắng đực 120 con, đủ tiêu chuẩn thí nghiệm, được chia thành các lô:

- Lô chứng phẫu thuật $(n=30)$ : phẫu thuật không gây nhồi máu + uống nước cất.

- Lô chứng nhồi máu ( $n=30)$ : phẫu thuật gây nhồi máu + uống nước cất.

- Lô LK $(n=30)$ : phẫu thuật gây nhồi máu + uống thuốc LK tái tổ hợp liều $200 \mathrm{mg} / \mathrm{kg}$.

- Lô Boluoke $(n=30)$ : phẫu thuật gây nhồi máu + uống thuốc tham chiếu Boluoke liều $200 \mathrm{mg} / \mathrm{kg}$.

Thuốc (LK tái tổ hợp, Boluoke) được hòa tan trong nước cất $(\mathrm{NC})$ và cho chuột uống qua kim cong đâuu tù. Ngày 0 (ngày phẫu thuật) chuột được uống thuốc hoặc nước cất tại thời điểm 3 giờ sau phẫu thuật. Những ngày tiếp theo, chuột được cho uống mỗi ngày 1 lần lúc 3 giờ chiều. Thể tích cho uống là $0,1 \mathrm{ml} / 10 \mathrm{gram}$ thể trọng.

*Đánh giá tác dụng của thuốc trên mức độ tổn thương chức năng thần kinh của chuột trong giai đoạn cấp

Để đánh giá tác dụng của thuốc trên mức độ tổn thương chức năng thần kinh của chuột trong giai đoạn cấp, các hoạt động vận động tại các 
thời điểm 24h trước khi gây đột quị, 6h, 24h, $48 \mathrm{~h}$ và $72 \mathrm{~h}$ sau khi gây đột quị được đánh giá và so sánh giữa các lô chuột.

- Để đánh giá mức độ tổn thương vân động của chuột đột quị, Clark và cộng sự (1997) đã đưa ra thang điểm gồm 7 tiêu chí đánh giá, mỗi tiêu chí được cho điểm từ 0 đến 4 . Mức độ tổn thương nặng nhất là 28 điểm. Cách cho điểm theo thang điểm của Clark được trình bày ở bảng 1 [5].

Bảng 5 :Thang điểm giá mức độ tổn thương vận động của chuột

\begin{tabular}{|c|c|c|c|c|c|}
\hline Điểm & 0 & 1 & 2 & 3 & 4 \\
\hline $\begin{array}{l}\text { 1. Thăng bằng cơ thế } \\
\text { (nhìn tữ trên xuống) }\end{array}$ & $\begin{array}{l}\text { Bình thường } \\
\text { (bt) }\end{array}$ & Thay đổi nhẹ & $\begin{array}{c}\text { Thay đối trung } \\
\text { bình }\end{array}$ & $\begin{array}{l}\text { Thay đối } \\
\text { dế thấy }\end{array}$ & $\begin{array}{c}\text { Thay đối } \\
\text { nghiêm trọng }\end{array}$ \\
\hline 2. Dáng đi & $\mathrm{Bt}$ & Cứng & Khập khiêng & Run, ngã & Không đi được \\
\hline 3. Trèo dốc $45^{0}$ & Bt & Trèo yếu & $\begin{array}{l}\text { Giữ đứng } \\
\text { tại dốc }\end{array}$ & Nằm tại dốc, ngã & $\begin{array}{c}\text { Không chuyên } \\
\text { động }\end{array}$ \\
\hline $\begin{array}{l}\text { 4. Hướng di chuyến } \\
\text { (thẳng hay xoay } \\
\text { vòng) tự nhiên }\end{array}$ & \begin{tabular}{|c|} 
Di chuyến \\
thẳng, không \\
xoay vòng \\
\end{tabular} & $\begin{array}{l}\text { Lật nghiêng } \\
\text { chư yếu một } \\
\text { bên }\end{array}$ & \begin{tabular}{|c|}
$\begin{array}{c}\text { Xoay một bên } \\
\text { nhưng khônng } \\
\text { ổn định }\end{array}$ \\
\end{tabular} & $\begin{array}{c}\text { Xoay môt bên ổn } \\
\text { định }\end{array}$ & $\begin{array}{l}\text { Không chuyển } \\
\text { động }\end{array}$ \\
\hline $\begin{array}{l}\text { 5. Hướng di chuyến } \\
\text { khi bị kéo đuôii (xoay } \\
\text { cưỡng bức) }\end{array}$ & $\begin{array}{l}\text { Không có biểu } \\
\text { hiện xoay vòng }\end{array}$ & $\begin{array}{l}\text { Xu hướng lật } \\
\text { một bên }\end{array}$ & Xoay một bên & $\begin{array}{l}\text { Xoay một bên } \\
\text { chậm }\end{array}$ & $\begin{array}{c}\text { Không chuyển } \\
\text { động }\end{array}$ \\
\hline $\begin{array}{l}\text { 6. Thăng bằng chân } \\
\text { trước sau }\end{array}$ & Bt & $\begin{array}{l}\text { Không thăng } \\
\text { bằng nhẹ }\end{array}$ & $\begin{array}{c}\text { Không thăng } \\
\text { bằng rõ }\end{array}$ & $\begin{array}{l}\text { Không thăng } \\
\text { bằng nghiêm } \\
\text { trọng }\end{array}$ & $\begin{array}{l}\text { Không vận } \\
\text { động cớ } \\
\text { thể/chân }\end{array}$ \\
\hline $\begin{array}{l}\text { 7. Đáp ứng với chạm } \\
\text { nhẹ phía sau }\end{array}$ & $\begin{array}{l}\text { Đáp ứng một } \\
\text { cách tự nhiền }\end{array}$ & $\begin{array}{l}\text { Mất thăng } \\
\text { bằng nhẹ }\end{array}$ & $\begin{array}{l}\text { Mất thăng } \\
\text { bằng rõ }\end{array}$ & $\begin{array}{l}\text { Không đáp ứng } \\
\text { cùng bên, giảm } \\
\text { đáp ứng đối bên }\end{array}$ & $\begin{array}{l}\text { Không đáp } \\
\text { ứng cả hai bên }\end{array}$ \\
\hline
\end{tabular}

- Đánh giá khả năng vận động chủ động của chuột. Mỗi chuột được đặt trong hộp nhựa, kích thước 30 x 50cm. Hoạt động vận động của chuột ỏ trong hộp nhựa được ghi lại trong 5 phút bằng camera nối với máy tính. Phẩn mềm máy tính sẽ tự động phân tích tổng quãng đường di chuyển và vần tốc di chuyển trung bình của chuột.

4. Xử lý số liệu. Các số liệu được xử lý theo các phương pháp thống kê y sinh học, so sánh bằng anova test sử dụng phần mềm SPSS 16.0. Sự khác biệt có ý nghĩa thống kê khi $\mathrm{p}<0,05$.

5. Địa điểm tiến hành nghiên cứu: Tại bộ môn dược lý, Viện đào tạo Dược - Học viện quân y

\section{KẾT QUẢ NGHIÊN CỨU}

1. Kết quả đánh giá mức độ gây tổn thương vận động theo thang điểm của Clark: Trước khi tiến hành phẫu thuật, hoạt động vận động của tất cả các chuột ở các lô bình thường, điểm đánh giá theo thang điểm của Clark bằng 0 . Sau khi tiến hành phẫu thuật, hoat động vận động của lô chứng phẫu thuật (phấu thuật không gây nhồi máu) vẫn bình thường chứng tỏ các bước phẫu thuật bộc lộ động mạch não giữa không gây ảnh hưởng đến chức năng thần kinh não chuột. Chuột ở các lô gây nhồi máu máu não có các biểu hiện tổn thương thần kinh rõ khi đánh giá theo thang điểm Clark. Do gây nhồi máu não tại động mạch não giữa bên phải, chuột yếu cơ ở nửa thân bên trái, các cơ ở nửa thân bên phải co mạnh hơn làm chuột có xu hướng xoay vòng về bên phải.

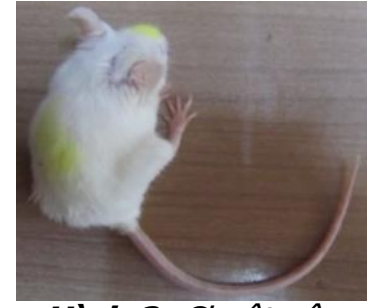

Hình 2: Chuột gây nhồi máu, tư thế di chuyển xoay vòng về bên tổn thương

\section{Kết quả đánh giá mú}

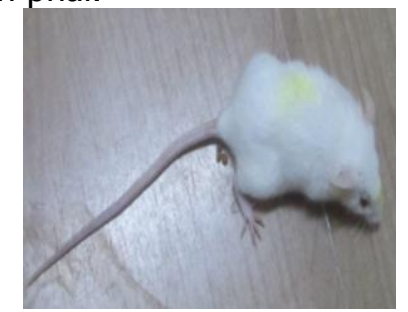

Hình 3: Chuột không gây nhồi máu, tư thế di chuyển binh thường mức độ suy giảm hoạt động vận động theo thang điểm của Clark của chuột ở các lô gây nhồi máu được trình bày ở bảng 2 .

Bảng 6: Kêt quả đánh giá mức độ suy giảm hoạt động vận động theo thang điểm của Clark

\begin{tabular}{|c|c|c|c|c|}
\hline \multirow[b]{2}{*}{$\begin{array}{l}\text { Thời điểm } \\
\text { đánh giá }\end{array}$} & \multicolumn{4}{|c|}{ Điếm đánh giá theo thang điếm Clark $(x \pm S E, n=30)$} \\
\hline & $\begin{array}{l}\text { Lỗ chứng } \\
\text { phấu thuâtt }\end{array}$ & $\begin{array}{l}\text { Lô chứng nhồi máu } \\
\text { (uống nước cất) }\end{array}$ & $\begin{array}{l}\text { Lố LK (uống LK } \\
200 \mathrm{mg} / \mathrm{kg} \text { ) }\end{array}$ & $\begin{array}{c}\text { Lô Boluoke (uống } \\
\text { Boluoke } 200 \mathrm{mg} / \mathrm{kg} \text { ) }\end{array}$ \\
\hline & 0 & $12,86 \pm 0,30$ & $12,20 \pm 0,35$ & $12,15 \pm 0,32$ \\
\hline Sau 24h & 0 & $11,65 \pm 0,25$ & $10,86 \pm 0,42^{*}$ & $10,62 \pm 0,37^{*}$ \\
\hline
\end{tabular}




\begin{tabular}{|c|c|c|c|c|}
\hline Sau 48h & 0 & $11,12 \pm 0,26$ & $10,02 \pm 0,32^{*}$ & $9,88 \pm 0,28^{*}$ \\
\hline $\mathrm{sau} / \angle \mathrm{n}$ & 0 & $10,8< \pm 0,<4$ & $9,25 \pm 0,29^{*}$ & $y, 10 \pm 0,217$ \\
\hline \multicolumn{3}{|c|}{ 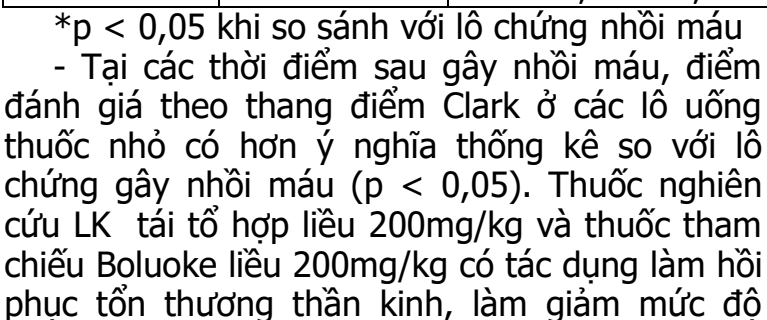 } & \multicolumn{2}{|c|}{$\begin{array}{l}\text { tổn thương vận động của các chuột gây nhồi } \\
\text { máu não. } \\
\text { - So sánh giữa } 2 \text { lô LK và lô Boluoke, taai tất } \\
\text { cả các thời điểm đánh giá, sự khác biệt không có } \\
\text { ý nghĩa thống kê. Với cùng mức liều } 200 \mathrm{mg} / \mathrm{kg} \text {, } \\
\text { thuốc nghiên cứu LK có tác dưng làm hồi phục } \\
\text { tổn thương vận động do nhồ máu não tương } \\
\text { đương với thuốc tham chiếu Boluoke. }\end{array}$} \\
\hline
\end{tabular}

2. Kết quả đánh giá khả năng vận động chủ động

Bảng 7: Chiều dài quãng đường di chuyển (cm) khi đo vận động chủ động của các lô chuột trong vòng 5 phút

\begin{tabular}{|c|c|c|c|c|}
\hline \multirow{2}{*}{$\begin{array}{c}\text { Thời điểm đánh } \\
\text { giá }\end{array}$} & \multicolumn{4}{|c|}{ Chiều dài quãng đường di chuyến $(\mathrm{cm})(X \pm S E, n=30)$} \\
\hline & $\begin{array}{l}\text { Lố chứng } \\
\text { phẫu thuất }\end{array}$ & $\begin{array}{l}\text { Lô chứng } \\
\text { nhồi máu }\end{array}$ & Lô LK & Lô B \\
\hline Trước p & $1988,41 \pm 168,45$ & $1995,25 \pm 168,41$ & 192 & 197 \\
\hline Sau 6 & $1012,28 \pm$ & $102,24 \pm 14,71$ & $110,96 \pm 13,61$ & $115,85 \pm 16,27$ \\
\hline Sau 24h & & 46 & $704,86 * \pm 41,25$ & $712,24 *$ \\
\hline Sau $48 \mathrm{~h}$ & 71 & 868,1 & $1002,43 * \pm 43,91$ & $1068,32 * \pm 51,26$ \\
\hline Sau $72 \mathrm{~h}$ & $1962,40 \pm 148,56$ & $972,63 \pm 58,20$ & $1164,85^{*} \pm 61,44$ & $1201,64 * \pm 59,72$ \\
\hline
\end{tabular}

*p $<0,05$ khi so sánh với lô chứng nhồi máu

- Tại các thời điểm sau phẫu thuật, quãng đường di chuyển của chuột ở các lô có dùng thuốc dài hơn có ý nghĩa thống kê so với lô chứng nhồi máu với $\mathrm{p}<0,05$. Thuốc nghiên cứu LK tái tổ hợp liều $200 \mathrm{mg} / \mathrm{kg}$ và thuốc tham chiếu Boluoke liều $200 \mathrm{mg} / \mathrm{kg}$ có tác dụng làm hồi phục tổn thương thần kinh, giúp chuột hồi phục vận

động chủ động tốt hơn so với lô chứng nhồi máu.

- So sánh giữa 2 lô LK và lô Boluoke, tại tất cả các thời điểm đánh giá, sự khác biệt không có ý nghĩa thống kê. Với cùng mức liều $200 \mathrm{mg} / \mathrm{kg}$, thuốc nghiên cứu LK có tác dụng làm hồi phục vận động chủ động tương đương với thuốc tham chiếu Boluoke.

Bảng 8: Vận tốc di chuyển trung bình (cm/giây) khi đo vận động chủ động của các lô chuột trong vòng 5 phút.

\begin{tabular}{|c|c|c|c|c|}
\hline \multirow{2}{*}{$\begin{array}{c}\text { Thời điểm đánh } \\
\text { giá }\end{array}$} & \multicolumn{4}{|c|}{ Vận tốc di chuyến trung bình (cm/giây) $(x \pm S E, n=30)$} \\
\hline & $\begin{array}{c}\text { Lô̂ chứng } \\
\text { phâ̂u thuật }\end{array}$ & $\begin{array}{l}\text { Lô chứng } \\
\text { nhôii máu }\end{array}$ & Lô LK & Lô Boluoke \\
\hline Trước phâu thuật & $7,42 \pm 0,46$ & $7,50 \pm 0,41$ & $7,57 \pm 0,39$ & $7,21 \pm 0,42$ \\
\hline Sau $6 \mathrm{~h}$ & $6,21 \pm 0,38$ & $0,92 \pm 0,24$ & $0,98 \pm 0,21$ & $1,01 \pm 0,23$ \\
\hline Sau 24h & $7,03 \pm 0,42$ & $1,85 \pm 0,28$ & $2,82 * \pm 0,25$ & $2,86^{*} \pm 0,27$ \\
\hline Sau $48 \mathrm{~h}$ & $7,19 \pm 0,49$ & $2,71 \pm 0,34$ & $3,49 * \pm 0,31$ & $3,52 * \pm 0,35$ \\
\hline Sau 72h & $7,25 \pm 0,51$ & $3,05 \pm 0,26$ & $4,12 * \pm 0,31$ & $4,18^{*} \pm 0,29$ \\
\hline
\end{tabular}

*p $<0,05$ khi so sánh với lô chứng nhồi máu

- Sau phẫu thuật, các lô chuột gây nhồi máu có vận tốc di chuyển trung bình giảm rõ rệt.

- Tại các thời điểm sau phẫu thuật 24hi, 48h, và $72 h$, vận tốc di chuyển trung bình của chuột ở các lô có dùng thuốc (LK hoặc Boluoke) lớn hơn có ý nghĩa thống kê so với lô chứng nhồi máu với $\mathrm{p}<0,05$. Thuốc nghiên cứu LK tái tổ hợp liều $200 \mathrm{mg} / \mathrm{kg}$ và thuốc tham chiếu Boluoke liều $200 \mathrm{mg} / \mathrm{kg}$ có tác dụng làm hồi phục tổn thương thần kinh, giúp chuột hồi phục vận động chủ động tốt hơn so với lổ chứng nhồi máu.

- So sánh giữa 2 lô LK và lô Boluoke, tại tất cả các thời điểm đánh giá, sự khác biệt không có ý nghĩa thống kê. Với cùng mức liều $200 \mathrm{mg} / \mathrm{kg}$,

thuốc nghiên cứu LK có tác dụng làm hồi phục vận động chủ động tương đương với thuốc tham chiếu Boluoke.

\section{BÀN LUẬN}

- Mô hình gây nhồi máu não trên động vật thực nghiệm được sử dụng trong nghiên cứu này cho phép tạo ra một cục máu đông có bản chất sát với thực tế lâm sàng. Cục máu đông được tạo ra bởi chính quá trình tự đông máu của chuột (cục đông máu tự thân) đó khi yếu tố gây đông máu (thrombin) tằng cao trong lòng mạch. Mô hình này cho phép thử tác dụng của các thuốc làm tan huyết khối. Một số mô hình khác 
cũng gây nhồi máu não nhưng chỉ thích hợp để nghiên cứu cơ chế bệnh sinh, không phù hợp cho nghiên cứu đánh giá tác dụng của thuốc tan huyết khối. Chẳng hạn mô hình gây nhồi máu bằng cách chiếu tia lase vào mạch máu, làm máu có chứa hóa chất nhạy cảm với ánh sáng (như Erythrosin $B$, được tiêm vào mạch trước đó) đông lại, thì bản chất cục máu đông này hoàn toàn khác với cục máu đồng tự nhiên.

- Mô hình nhî̀i máu não được sử dụng có ưu điểm ít gây tổn thương đối với động vật thí nghiệm, sau khi đã thành thạo với kỹ thuật mổ chuột và tiêm thrombin, không có chuột bị chết, và cũng không có xuất huyết não gây ra do phẫu thuật, cho phép kết quả thử nghiệm có độ chính xác cao. Ưu điểm thứ hai của mô hình là gây ra cục nhồi máu não cũng như vùng tổn thương não tương đối ổn định. Cục máu đông luôn được đặt ở đúng vị trí so với các mô hình khác thường yểu câu tiêm một số lượng lớn cục máu đông được tạo sẵn để thúc đẩy quá trînh tắc MCA. Những cục máu đông này có thể dẫn đến tắc thứ phát trong các mạch nhỏ hơn và sự biến đổi sau đó của các tổn thương do thiếu máu cục bộ đo được, cũng làm tăng mức độ tử vong. Ngược lại, mô hình hiên tại dẫn đến sự hình thành cục máu đông với tổn thương não chính xác và có thể tái tạo được. Nó cho phép tính lặp lại cũng như độ chính xác của thử nghiệm cao

- Khả năng vận động chủ động (hay hoạt động vận động tự nhiển) cho phép đánh giá cả hoạt động tâm thần kinh (kích thích gây hưng phấn làm tăng hoạt động vận động hay ức chế làm giảm hoạt động vận động), cả mức độ tổn thương thực thể vận động (gây bại, liệt cơ, đánh giá bằng thang điểm Clark). Khi gây nhồi máu tại động mạch não giữa, tổn thương trên não gây ức chế làm giảm hoạt động vận động của chuột. Mức độ bị nhồi máu của chuột càng nhiều, chuột càng giảm hoạt động vận động chủ động. Các chuột gây nhồi máu não hoạt động chầm chạp hơn hẳn so với các chuột ở lồ chứng phầu thuật không gây nhồi máu. Trong nghiên cứu có thể thấy được quãng đường di chuyển trung bình và vận tốc di chuyển trung bình của chuột trong 5 phút giảm rõ rệt sau khi gây nhồi máu ở động mạch não giữa, tuy nhiên sau khi sử dụng thuốc lumbrokinase tái tổ hợp hay thuốc tham chiếu Boluoke với cùng mức liêuu thì chuột có biểu hiện hồi phục khả năng vận động chủ động khi quãng đường di chuyển và vận tốc di chuyển trung bình của chuột tăng rõ rệt so với lô không sử dụng thuốc.

- Lumbrokinase làm tan huyết khối thông qua cơ chế tác dụng trực tiếp thuỷ phân fibrin, ngoài ra còn có tác dụng hoạt hoá plasminogen thành plasmin, từ đó plasmin thuỷ phân fibrin. Tác dụng của lumbrokinase tái tổ hợp được so sánh với Boluoke (lumbrokinase) của Canada RNA Biochemical Inc là thuốc chuẩn đã được sử dụng rộng rãi trên lâm sàng và cho hiệu quả điều trị tốt. Trên mô hình thử nghiệm, với cùng mức liều $200 \mathrm{mg} / \mathrm{kg}$, thuốc lumbrokinase tái tổ hợp có tác dụng hồi phục chức năng vận động của chuột gẩy nhồi máu ở động mạch não giữa trong giai đoạn cấp tương đương với thuốc tham chiếu Boluoke. Kết quả này, cùng với những kết quả phân tích kiểm nghiệm thuốc đã được nghiên cứu trước đó, là cơ sở khoa học tin cậy cho việc thử nghiệm thuốc trên lâm sàng.

- Thuốc LK tái tổ hợp dùng trong thử nghiệm ở dạng uống. Dạng uống thường được sử dụng trong dự phòng và điều trị củng cố, do đường uống thường có tác dụng chậm và kém hơn so với đường tiêm. Trong thử nghiệm ta thấy thuốc đã thể hiện tác dụng rõ ngay cả khi đánh giá ở giai đoạn cấp (3 ngày đầu). Kết quả đó chứng tỏ thuốc có tác dung tốt trong giai đoạn cấp và chúng tôi cho rằng nếu có thể bào chế được ở dạng tiêm thì hiệu quả điều trị sẽ được tăng cường lên nhiều, do bệnh lý đột quị não là bệnh lý cấp tính.

\section{KẾT LUẦN}

- Đã triển khai được mô hình gây nhồi máu não trên động vật thực nghiệm sát với thực tế lâm sàng và phù hợp để đánh giá tác dụng của những thuốc tiêu sợi huyết dùng cho điều trị nhồi máu não. Đồng thời cũng đã triển khai được bộ các thử nghiệm dùng trong đánh giá tác dụng của thuốc trên mô hình xây dựng được.

- Thuốc lumbrokinase tái tổ hợp mức liêu $200 \mathrm{mg} / \mathrm{kg}$ có tác dụng tốt trong việc hồi phục tổn thương não trên mô hình thực nghiệm, làm giảm mức độ tổn thương vận động của chuột trong 3 ngày đầu sau gây nhồi máu não. Thuốc có tác dụng tốt trong việc hồi phục vận động chủ động của chuột ở trong giai đoạn cấp. Các tác dụng này của lumbrokinase tái tổ hợp tương đương với thuốc chuẩn Boluoke (lumbrokinase) của Canada RNA Biochemical Inc được sử dụng làm thuốc tham chiếu trong nghiên cứu.

\section{TÀI LIẸU THAM KHẢO}

1. PGŚ.TS. Nguyến Minh Hiện. Đột quy não. Nhà xuất bản Y học. Hà Nội 2013.

2. Rosamond $\mathbf{W}$, Flegal $K$, Furie $K$, et al. Heart disease and stroke statistics-2008 update: a report from the American heart association statistics committee and stroke statistics subcommittee. Circulation. 2008;117(4):e25-e46 
3. Kotb, E. (2014), "The biotechnological potential of fibrinolytic enzymes in the dissolution of endogenous blood thrombin", Biotechnology progress.

4. Cyrille Orset et al (2007), Mouse Model of In Situ Thromboembolic Stroke and Reperfusion,
Stroke.38:2771-2778.

5. Clark W, Gunion-Rinker $L$, Lessov $N$, Hazel $K$, Macdonald RL. Citicoline treatment for experimental intracerebral hemorrhage in mice. Stroke. 1998, 29, pp. 2136-2140.

\title{
ĐÁNH GIÁ KẾT QUẢ LÂU DÀI CỦA PHẪU THUÂT PHACO CÓ ĐĂT THỦY TINH THỂ NHÂN TẠO TẠI BỆNH VIỆN ĐA KHOA TỈNH QUẢNG NINH
}

\author{
Lưu Đức Hà1, Cung Hồng Sơn ${ }^{2}$, \\ Vũ Anh Tuấn ${ }^{3}$, Lương Thị Hải Hà ${ }^{4}$
}

\section{TÓM TẮT}

Mục tiêu: Đánh giá kết quả lâu dài của phẫu thuật phaco có đặt thủy tinh thể nhân tạo tại Bệnh viện đa khoa tỉnh Quảng Ninh. Đối tượng và phương pháp: Nghiên cứu được tiến hành trên 123 mắt được phẩu thuật Phaco và đăt thủy tinh thể nhân tạo tai BV Đa khoa tỉnh Quảng Ninh. Nghiên cứu mô tả cắt ngang. Kết quả: Tuối trung bình của bệnh nhân là $71,70 \pm 7,75$, tỷ lệ nam nhỏ hơn nữ tương ứng là $47,8 \%$ so với $52.2 \%$, phần lớn là đục thủy tinh thể do tuổi già 115 mắt $(93,5 \%)$, thị lực sau chỉnh kính có tới 106 mắt $(86,2 \%)$ thị lực trền $20 / 40$, số mắt có độ loan 1.00 đến $\leq 2.00$ Diop trước phấu thuât là 31 mắt $(25,2 \%)$, tại thời điểm nghiên cứu là 46 mắt $(37,4 \%)(p<0,05)$, có 5 biến chứng phát hiện ở thời điểm nghiên cứu: Đục bao sau là biến chứng gặp nhiều nhất với $69,1 \%$, tiếp đến là xơ hóa co kéo vòng xé bao $52,8 \%$, rách bao sau là 3,3\%. Kết luận: Biến chứng lâu dài gặp nhiều nhất sau phẫu thuật là loan thị, đục bao sau, xơ hóa co kéo vòng kéo bau và rách bao sau

Từ khóa: Thị lực, phaco, thủy tinh thể nhân tạo,...

\section{SUMMARY}

\section{ASSESSMENT OF LONG-TERM RESULTS OF PHACO SURGERY IN GENERAL HOSPITAL QUANG NINH PROVINCE}

Objective: Assessment of long-term results of Phaco surgery in general hospital Quang Ninh province. Methods: The study was conducted on 123 eyes of 67 patients were been surgery Phaco in general hospital Quang Ninh province. Cross-sectional descriptive study. Results: The mean age of the patients was $71.70 \pm 7.75$, the men were smaller than women $(47.8 \%$ and $52.2 \%)$, most of them were cataracts due to old age 115 eyes $(93.5 \%)$, ), good

\footnotetext{
${ }^{1}$ Bệnh viện Đa khoa Tỉnh Quảng Ninh,

${ }^{2}$ Bênh viện Mắt Trung Uơng

3 Trường Đại học Y Hà Nội,

${ }^{4}$ Trường Đại học Y Dược Thái Nguyên

Chịu trách nhiệm chính: Lưu Đức Hà

Email: dr.luuducha@gmail.com

Ngày nhận bài: 9.9.2021

Ngày phản biện khoa học: 29.10.2021

Ngày duyệt bài: 10.11.2021
}

visual acuity 106 eyes (86.2\%), the eyes with astigmatism 1.00 to $\leq 2.00$ Diop before surgery was 31 eyes $(25.2 \%)$, the study included 46 eyes $(37.4 \%)$ $(p<0.05)$, there were 5 complications detected: opaque posterior capsule was the most common complication with $69.1 \%$, pull posterior capsule was $52.8 \%$ and gash posterior capsule was $3.3 \%$. Conclusion: The most common long-term complications after surgery are astigmatism, opaque posterior capsule, gash posterior capsule.

Key words: Vision acuty, phaco, IOL,...

\section{I. ĐẶT VẤN ĐỀ}

Bênh đục thủy tinh thể là môt trong nhũng nguyên nhẩn hàng đầu gây mù lìa ở Việt Nam cũng như trên thế giới. Điều trị nội khoa đục thủy tinh thể chỉ có tác dụng rất hạn chế, một số thuốc như sorbitol, aspirin, vitamin $C$ và $E$ chủ yếu được sử dung để dự phòng đục thủy tinh thể bằng chế độ dinh dưỡng hợp lý và tránh các yếu tố nguy cơ [1],[2]. Điều trị ngoại khoa đục thủy tinh thể mới giải quyết triệt để được bệnh và là môt trong những vấn đề có tính chất toàn cầu nhằm hạ thấp tỷ lệ đục thủy tinh thể, giảm tỷ lệ mù lòa, nâng cao chất lượng lao động và cuộc sống của con người [3],[4].

Ngày nay, với sự tiến bộ không ngừng của vi phẫu thuật, phẫu thuật làm nhuyễn thủy tinh thể bằng năng lượng siêu âm (Phacoemulsification) gọi tắt là phẫu thuật Phaco là phẫu thuật khá an toàn, ít biến chứng, phục hồi thị lực nhanh chóng và tối đa cho người bệnh. Phương pháp này có rất nhiều ưu điểm: vết mổ nhỏ, do đó giảm độ loạn thi; vết mổ nhanh liền, rút ngắn thời gian hậu phấu; đem lại thị lực cao cho bệnh nhân ngay từ những ngày đầu sau mổ do vậy là lựa chọn điều trị đục thể thuỷ tinh hàng đầu của các bác sĩ nhãn khoa [1],[4].

Bệnh võng mạc đái tháo đường là một trong những nguyên nhân hàng đầu gây mất thị lực trên thế giới. Nếu không được điều trị và phát hiện kịp thời sẽ gây ra những tổn thương nặng nề ở đáy mắt như: phù hoàng điểm, tân mạch 